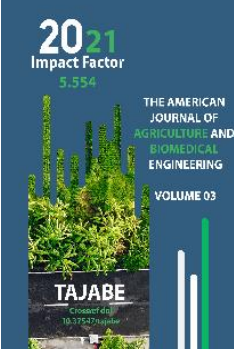

Journal Website: https://theamericanjou rnals.com/index.php/ta jabe

Copyright: Original content from this work may be used under the terms of the creative commons attributes 4.0 licence.

\section{Potato Pests In Uzbekistan}

\author{
Dilshod Obidzhanov \\ Doctor of philosophy of agricultural sciences, senior researcher, Uzbek research institute of \\ plant protection, Uzbekistan
}

Kholbek Erkinov

Magistr, TashDAU, Uzbekistan

\title{
ABSTRACT
}

More than 10 kinds of the basic pests have been revealed in the territory of various soil-climatic zones of the Republic. Among them are adventive kinds -the Colorado potato beetle, the whitefly and the potato moth. Biological features of kinds and seasonal dynamics of their development are established; the general tactic of protective methods with application of progressive means and receptions is developed. Precautionary receptions of potato tubers' protection against potato moth are established and recommended.

\section{KEYWORDS}

Colorado potato beetle, potato moth, rust mite, whitefly, biology, insecticides, ways of protection, efficiency

\section{INTRODUCTION}

The potato manufacture is an integral part of agriculture in Uzbekistan. For the last two decades the potato manufacture reached a necessary quantity that allowed minimizing its import. Nowadays the total area occupied under potato is over 100 thousand hectares in the Republic.
It is necessary to notice that potato cultivation in extreme, sharply continental conditions of the Central Asia is not convenient. In other words, environmental conditions of Uzbekistan and other neighboring countries are not favorable for potato cultivation. In conditions of high summer temperatures and 
low relative humidity of air the potato does not fructify well and degenerates. Therefore it is accepted to sow a potato under our conditions two times a year- early - March-June and, late - July-October. Nevertheless, the certain part of a potato degenerates and we are to import a seed potato.

Our potato differs from European one by less infection with diseases, in particular, with phytophthora and virus diseases. But there is also the relative increase of infected areas because of general tendency of expansion of false- powdery mildew fungi and diseases to the Central Asia.

It also concerns the list of potato pests and replenishment by its new kinds. So, it was considered in 6oth of the last century that Colorado potato beetle (Leptinotarsa decemlineata Say.) cannot adapt to extreme living conditions, for example in Uzbekistan. But, to the contrary, the kind has penetrated having punched a barrier of quarantine and successfully accustomed in the territory of the Republic in 1978-1980. And since then the Colorado potato beetle began to develop in the status of adventive kinds in the territory on canons to be scientifically defined in article of N.A.Vilkova, etc. (2005). The high eurybiontness and ecological plasticity of a kind (Ushatinskaya, 1981, Fasulati, 1985) promoted the Colorado potato beetle to adapt perfectly, to expand the area and to harm to the republic potato growing. However, a high injuriousness of a kind peculiar to the beginning of penetration of a kind (Ushatinskaya, 1981; N.A.Vilkova, etc., 2005; Hare, 1990; Khodzhaev, 2013) changed after 2000th by more moderate density and percent of plants settling.
Despite the aforesaid, the general losses of a potato crop from pests and diseases against applied measures make not less than the fifth part of a potential crop. There is a share of cut worms and other terricolous pests (wireworms, etc.); suctorian pests; tomato and rust mite (Aculops lycopersici W.), whitefly and tobacco thrips (especially in the conditions of the Khorezm region and the Republic of Karakalpakstan). It is necessary to note some adventive kinds of insects as gnawing pests of an elevated part of potato plants: the Colorado potato beetle and more recently delivered the potato moth - Phthorimaea operculella Zell. Studying of bio-ecological features of development, injuriousness and development of effective means and methods of their control in various conditions of the Republic have been our researches for the last years.

Place and technique of researches. Monitoring of susceptibility to infection of a potato by pests was spent all over the territory of the Republic, and experiments and routing supervision were held on fields of Khorezm, Tashkent and Fergana regions. In research work the various methods recommended for these purposes (Gar, 1974; Dospekhov, 1979; Recommendations of Biological Monitoring Department of SRI, 1986; Khodzhaev, 2004) have been used.

The field plot experiments were spent on industrial crops of farmers. The size of allotments was $200 \mathrm{M} 2$ in a triple frequency. The processings spent by means of manual sprayers with a motor that provided good spraying and its relative uniformity, with calculated norm of the expense of a working liquid - 200-250 1/ha. For entomological accounts were randomized taken 20 test- 
The American Journal of Agriculture and Boimedical Engineering

(ISSN - 2689-1018)

IMPACT FACTOR

Published: July 30, 2021| Pages: 11-20

Doi: https://doi.org/10.37547/tajabe/Volume03Issue07-02

2021: 5.554

OCLC - 1121105746

plants, from each allotment. The following insecticides have been tested: Sayren-C, $55 \%$ c.e (concentrate of emulcy) . (500 g/l of Chloropiriphos $+50 \mathrm{~g} / \mathrm{l}$ of Cypremetrin, a fc Denmark), Enjoxam, 24,7 \% s.c. (141 g/l of Tiametoxam + $106 \mathrm{~g} / \mathrm{l}$ of Lambdacigalotrin, “BSM Agro Group” LtD, Uzbekistan), Aktara, $25 \%$ d.g.w. (dispersive granule in the water) (250 g/l of Tiametoxam, "Singenta", Switzerland), Imido, 35 \% s.c.. (350 g/l of Imidocloprid, “Ifoda” LtD, Uzbekistan), Karate, $5 \%$ c.e.. (50 g/l of Lambdacigalotrin, "Singenta", Switzerland).

Results of experiments and their discussion. The experiments concerned literally all principal kinds of potato pests. Along with study of biological features and injuriousness of the Colorado potato beetle we continued researches on improvement of measures of control against this kind. Nowadays many economies use a single processing against a bug and accompanying pests or do not process at all, in spite of the fact that in 200oth has been noticed a sharp fall of efficiency of used insecticides, especially of piritroids (Sukhoruchenko, etc., 2000; 2004; Khodzhaev, 2013). So, in 1980 - 1990th practically $100 \%-s^{\prime}$ efficiency by use of Carate (0,1 I/ha) against Colorado potato beetles and only $73-86 \%$ in 2014 (Tab. 1) has been received.

It follows from the table data that modern insecticides with participation of neonicotinoids' representatives (Aktara, Enjoxam, Imido), and also a mix- preparation Sayren-C with participation of FOS-Chlorpiriphosis have shown a high (close to $100 \%$ ) efficiency within considered 21 days after processing and can reliably protect the plants from Colorado potato beetles. For the efficiency indicator of insecticides against Colorado potato beetle (in particular) is not a constant size and it can change in due course, the new developments on preservation and augmentation of efficiency of protective means and methods are necessary. Certainly, one of such developments is a creation of Bt-transgenic grades of a potato according to authors (Shelton, 2004; Sukhoruchenko, etc., 2005). But, the reaction of the public to these developments is not identical. From the following potato pests to have an economic value it would be desirable to note whitefly (Aleyrodinea), aphids (Aphidinea) and tobacco Thrips (Thrips tabaci Lind.).

Table 1

\section{Biological efficiency of insecticides against Colorado potato beetle on a potato}

Field experiment, economy of Kibray E.S.U.E. 7/14/2014

\begin{tabular}{|c|c|c|c|c|c|c|c|c|c|c|c|c|}
\hline \multirow{3}{*}{$\begin{array}{l}\text { Experiment } \\
\text { variants }\end{array}$} & \multirow{3}{*}{$\begin{array}{c}\text { Norm of } \\
\text { preparati } \\
\text { ons } \\
\text { expense, } \\
\text { l (kg)/ ha }\end{array}$} & \multicolumn{6}{|c|}{$\begin{array}{c}\text { Average number of pests on a bush } \\
\text { of the plant (species) }\end{array}$} & & \multirow{2}{*}{\multicolumn{4}{|c|}{ Efficiency, in \% }} \\
\hline & & \multirow{2}{*}{$\begin{array}{c}\text { Before } \\
\text { proces } \\
\text { sing }\end{array}$} & \multicolumn{5}{|c|}{$\begin{array}{l}\text { After processing, at a date } \\
\text { of the account: }\end{array}$} & & & & & \\
\hline & & & 1 & 3 & & 14 & 21 & 1 & 3 & 7 & 14 & 21 \\
\hline
\end{tabular}


The American Journal of Agriculture and Boimedical Engineering

(ISSN - 2689-1018)

IMPACT FACTOR

Published: July 30, 2021| Pages: 11-20

Doi: https://doi.org/10.37547/tajabe/Volume03Issue07-02

2021: $5 \cdot 554$

OCLC - 1121105746

\begin{tabular}{|l|c|c|c|c|c|c|c|c|c|c|c|c|}
\hline $\begin{array}{l}\text { Sayren-C, } \\
55 \% \text { c.e. }\end{array}$ & 0,5 & 17,7 & 0,3 & 0 & 0,1 & 0,3 & 0,4 & 98,3 & 100 & 99,4 & 98,4 & 97,9 \\
\hline $\begin{array}{l}\text { Enjoxam, } \\
24,7 \% \text { s.c. }\end{array}$ & 0,15 & 23,3 & 0,2 & 0 & 0,1 & 0,2 & 0,3 & 99,1 & 100 & 99,6 & 99,2 & 98,8 \\
\hline $\begin{array}{l}\text { Aktara, 25\% } \\
\text { d.g.w. }\end{array}$ & 0,25 & 19,2 & 0,4 & 0,2 & 0,2 & 0,4 & 0,6 & 97,9 & 99,0 & 99,0 & 98,1 & 97,2 \\
\hline $\begin{array}{l}\text { Imido, 35\% s.c. } \\
\begin{array}{l}\text { Carate, 5\% } \\
\text { c.e.. } \\
\text { (Standard) }\end{array}\end{array}$ & 0,2 & 20,5 & 0,2 & 0 & 0,1 & 0,2 & 0,3 & 99,0 & 100 & 99,5 & 99,1 & 98,7 \\
\hline $\begin{array}{l}\text { Control } \\
\text { (without } \\
\text { rocessing) }\end{array}$ & - & 16,2 & 4,3 & 2,3 & 2,8 & 3,4 & 4,4 & 73,5 & 86,2 & 83,8 & 80,6 & 75,4 \\
\hline
\end{tabular}

The value of whiteflies as agricultural plants' pests has considerably increased with occurrence of tobacco (cotton) whitefly (Bemisia tabaci Genn.) in the territory of the Republic. It has occurred on a boundary of 1989-1990 on fields of more northern zone the Khorezm region. The whitefly was here so aggressive for the first years of occurrence that the human seemed to be powerless before this misfortune. Besides cotton, it strongly began occupying the other cultures and to harm a potato. The hothouse whitefly (Trialeurodes vaporariorum Westw.) has left into depression for summer but the tobacco thrips has not interrupted the intensive development. A fruit of scientific developments was the method of complex protection including organizationaleconomic, agro-technical, biological (application of encarzia, erythmocyrus), physic-mechanical (colour screens-traps) and chemical (use of piritroids).
The basic requirement to plants protection from whiteflies was a destruction of the pest in the conditions of re-wintering in hothouses and premises; for it was proved that the pest almost completely perishes in an open condition (Khodzhaev, 2013). In due course, the natural populations of specialized endoparasite - Encarzia formosa have increased so much that there was a natural oppression of the pest up to economic harmlessness. Nowadays, the whitefly infects a potato, but not up to the end. Sometimes there is a need for chemical intervention, but in MayJune. Rather effective remedies of insecticide protection of plants from whitefly are the representatives of neo-nicotinoids in a mix with hormonal preparations - Admiral or Applaud (0,5 l/ha). 

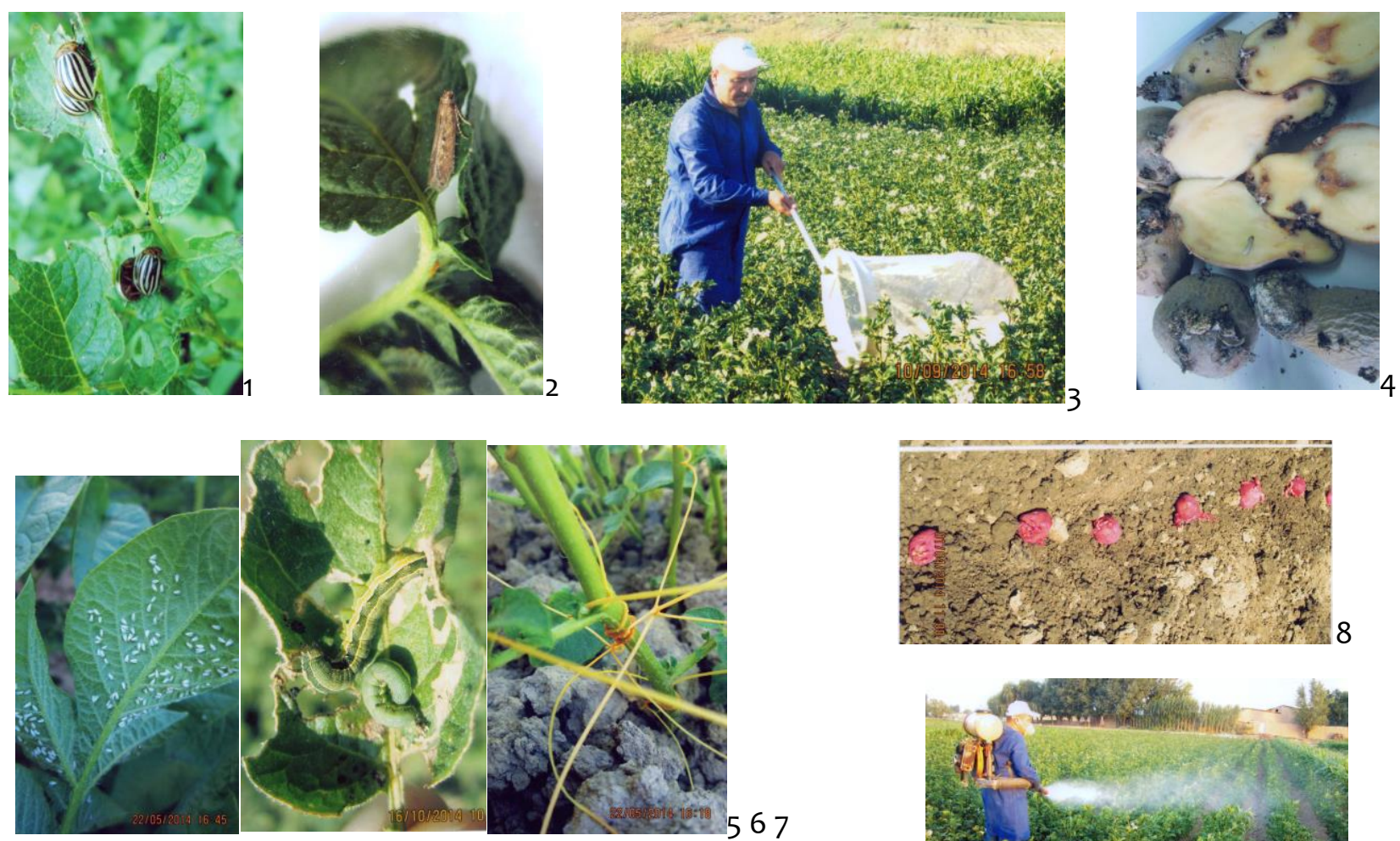

567
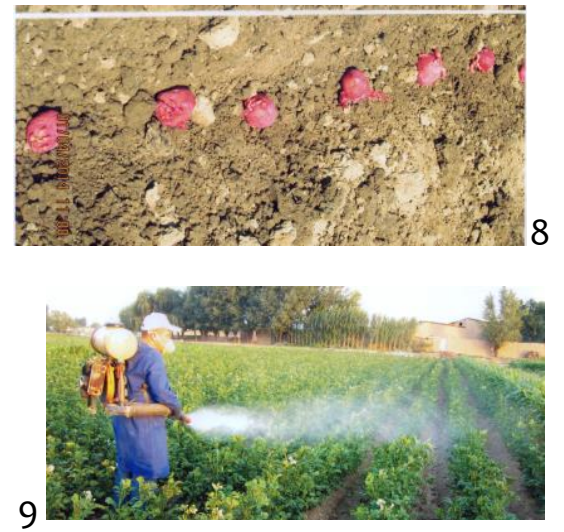

Fig.1 Potato pests and some ways of their control:

1 - Colorado beetles on the leaves; 2 - the butterfly of the potato moth; 3 - the account of butterflies by means of butterfly nets; 4 - the potato fruits damaged by caterpillars at storage, 5 whitefly, 6 - caterpillars of Caradrin; 7 - dodder (Cuscuta); 8 - crops by the pickled tubers; 9 spraying of plants by means of a manual sprayer with a motor.

In separate years, and not everywhere, the potato tops were populated with suctorian pests: plant aphids (Aphidinea), tobacco Thrips and rust mites (Aculops licopersici Massee). The special processings against plant aphids and Thrips had not been spent, considering them to be insufficiently harmful, but the rust mite demands a steadfast attention to itself (K.Mamatov's and B.Sulejmanov's dissertation works (1995) (1993) in due time have been devoted to). This representative of four-legged pincers family is so small that it is not visible under usual magnifiers (it is necessary to use more than 20x). It is extended everywhere; especially strongly it harms solanaceous potato and tomatoes (Mamatov, etc., 2013). The kind spreads together with insects, birds and labor instruments. The problem is that it is 
impossible to define the beginning of the infection, and when it comes to light, it happens already to be practically late - the considerable part of a crop is lost, the quantity of a crop worsens. Therefore, it is recommended to spend on annually infected sites anticipatory processings by one of the effective acaracides: Omite, Vertimec, Nissoran, Carate, etc.

For prevention of infection of tubers and a radical part of vegetable tops by caterpillars of cut worms (winter, exclamatory, etc.), wireworms, and also roots and tops fungi diseases, we tested a method of tubers preseeding processing with a complex of preparations consisting of protectants: Gaucho - $3 \mathrm{l} / \mathrm{t}$ and Maxim-XL - 1,5 l/t. At a field experiment of 2014 on the area of 0,75 hectares, the satisfactory efficiency of potato seeds processing method against winter cutworms, wireworms, root decay and a phytophthora in all forms of their display in comparison with control had been received. Researches in this direction to be continued.

On a boundary of 2009 in the territory of northern areas of the Republic the centers of potato moth (P.operculella) spreading rather quickly have been found out and nowadays it is registered on a half of the territory of the Republic (including the capital area). It was required to study urgently morphologicbiological features of development of a kind in new ecological conditions of habitation and to begin developments under the prevention of development and protection of plants and tubers from this new pest. The study began in 2010 by employees of UzSRIPP in the territory of the Khorezm region and is proceeding nowadays in the Tashkent region.

It is established that the basic part of the wintered butterflies of the moth appear from favorable winter storage conditions (cellars, storehouses, premises, etc.). Being a representative of kinds from the tropical countries an all-the-year-round continuous food is peculiar to it. In conditions of the Central Asia with snowless low winter temperatures of air the kind should not survive in the conditions of an open air. The publications also tell about it. According to V.N.Zhimerikin and V.M.Dudov (2009) the potato moth ceases to develop at air temperature $10^{\circ} \mathrm{C}$ and at $3-5^{\circ} \mathrm{C}$ it dies out. But there is no unambiguous answer. Some scientists consider that the kind can sometimes endure considerable colds up to $-8^{\circ} \mathrm{C}$ like in the South Korea (K.R. Choe, L.S. Park, 1982) - on V.A.Vlasova (1986).

Our researches have shown that butterflies' flight on fields continues to the late fall while the potato tops do not perish from the cold. Caterpillars inside the tubers also endure low temperatures and continue feeding on the potato until it is frozen. Thus, the pest has practically a possibility to winter in the field conditions in a stage of caterpillars being inside the earthed tubers (left after cleaning). Caterpillars inside the tubers do not perish at a storage time in cellars and storehouses, but duration of their development is stretched, nevertheless from November till next April they can give 2-3 generations (in warmer premises - up to 5 generations). So, the main task both in tubers' infections prevention and their preservations for storage, is maintenance of cleanliness of tubers left on storage. There are different conditions for this purpose in the Republic though it depends partly on precocity of grades. In northern conditions of the Khorezm region the colds come earlier, than at the other regions. It causes earlier destruction of potato tops. And consequently, prior to the beginning of harvesting the caterpillar have time having gone down from plants to penetrate into tubers. In other areas with 
The American Journal of Agriculture and Boimedical Engineering (ISSN - 2689-1018)

potato cultivation, the crop is usually harvested at green tops. It can be convenient, from the point of view that the tops of vegetable are mowed down and cleaned from a field before harvesting that does not allow tubers to be infected primary with caterpillars.
And, the second condition of prevention of tubers' infestation with butterflies' eggs rafting (especially at manual cleaning) is crop's fast cleaning from a field.

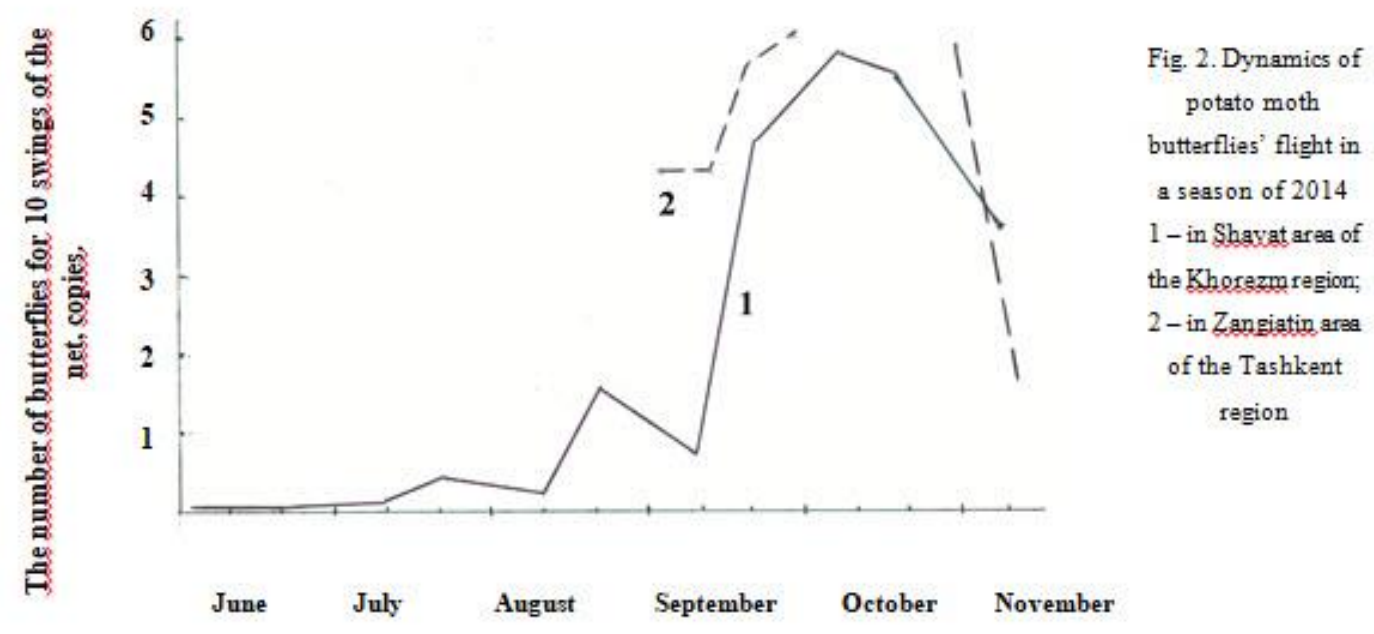

Studying of development phenology of a kind during a season has shown that butterflies' flight and their density occurs from small to bigger. In April it is possible to reveal the first butterflies of the moth, but they are very insignificant. Gradually by the autumn the butterflies' density increases and, to the beginning of September on 10 double waves of a net (see Fig.) come across to 7-8 butterflies of the moth. Fig. 2 presents the results of seasonal studying of potato moth butterflies' flight on potato fields in two geographically remote regions of the Republic.

From figure it follows that the basic part of potato moth dominates in SeptemberNovember both in one, and in other region.

Owing to recent penetration of potato moth to the territory of Uzbekistan, the pest has not many natural enemies yet. The entomophages need time to have been adapted to it.
For establishment of possibility of insecticides control against potato moth during growth of plants and establishment of the list of effective preparations, we provided a tactic of these processings and preparations testing. Tactics is that in view of practical impossibility of caterpillars' destruction inside the stalks, the scientifically-proved term of processings was the moment of mass flight and butterflies' eggs rafting. At absence of pheromone traps, these terms can be defined by insectary supervision over insects, and also butterflies' catch with nets in field conditions. It is required 3-4 processings for period of potato vegetation in this case. For achievement of the planned purpose is more comprehensible a tractor ventilatory sprayer OBX-28, but in small farm economy conditions the hinged manual sprayer with a motor (see Fig.) and having the expense of a working liquid to $250 \mathrm{l} /$ ha is quite enough. One of such experiments has been 
The American Journal of Agriculture and Boimedical Engineering (ISSN - 2689-1018)

spent for a season of 2014. A potato field of late term sowing has been divided into 8 plots (on $0,1 \mathrm{ha}$ ). On seven plots the various insecticides like imago and larvicides have been tested. There were 3 processings spent: on 29.VII, 10.IX and 24.IX. Accounts of butterflies' density were spent after each processing and of a biological efficiency - after the last processing within 11 days (Tab. 2). From the received results it follows that both the method and the tested insecticides have proved their value. No one potato tuber occupied by moth caterpillars has been found in comparison with control - 3,7$4,8 \%$. During wintering (from 9/6/2014 to
3/15/2015) the potato moth development among experimental tubers was not revealed, among control was $2,3-4,2 \%$.

Sometimes on potato tops it is possible to notice caterpillars of cotton worms (Helicoverpa armigera $\mathrm{Hb}$.) and caradrin (Spodoptera exqua Hb.) which occurrence is a general concern. Quite often on potato tops appears filicauline dodder (cuscuta) which control is to be spent locally.

Table 2

\section{Biological efficiency of 3 multiple processings of potato crops against potato moth and other accompanying pests}

Field experiment, the Tashkent region, the late term of crops $-25-27 . \mathrm{VII}$. ,

Processings are spent: 29.VIII, 10.IX and 24.IX.2017

\begin{tabular}{|c|c|c|c|c|c|c|c|c|c|c|c|}
\hline \multirow{3}{*}{$\begin{array}{c}\text { Experiment } \\
\text { variants }\end{array}$} & \multirow{3}{*}{$\begin{array}{c}\text { Active } \\
\text { substances of } \\
\text { preparations }\end{array}$} & \multirow{3}{*}{$\begin{array}{l}\text { Norms of } \\
\text { expense } \\
\text { on a } \\
\text { hectare, I } \\
\mathrm{kg} / \mathrm{ha}\end{array}$} & \multicolumn{9}{|c|}{ Efficiency, $\%$ on days of accounts: } \\
\hline & & & \multicolumn{5}{|c|}{ Against butterflies on a site: } & \multicolumn{4}{|c|}{$\begin{array}{l}\text { On decrease of plants } \\
\text { injuriousness after } \\
\text { the } 3 \text { rd processing: }\end{array}$} \\
\hline & & & 1 & 5 & 9 & 16 & 23 & 1 & 3 & 7 & 11 \\
\hline $\begin{array}{l}\text { Nurinol, } \\
55 \text { \% c.e.. }\end{array}$ & $\begin{array}{l}\text { Cypremetrin + } \\
\text { Chloropiriphos }\end{array}$ & 1,0 & 100 & $\begin{array}{c}87, \\
2\end{array}$ & $\begin{array}{c}81, \\
6\end{array}$ & 100 & $\begin{array}{c}98 \\
3\end{array}$ & 92,1 & $\begin{array}{c}96 \\
5\end{array}$ & $\begin{array}{c}95 \\
5\end{array}$ & $\begin{array}{c}94 \\
3\end{array}$ \\
\hline $\begin{array}{l}\text { Enjoxam, } \\
24,7 \% \text { к.с. }\end{array}$ & $\begin{array}{c}\text { Lambdacigalotri } \\
n+ \\
\text { Tiametoxam }\end{array}$ & 0,2 & 100 & $\begin{array}{c}88, \\
9\end{array}$ & $\begin{array}{c}89, \\
4\end{array}$ & 100 & $\begin{array}{c}99 \\
0\end{array}$ & $\begin{array}{c}90 \\
4\end{array}$ & $\begin{array}{c}97 \\
8\end{array}$ & $\begin{array}{c}95 \\
6\end{array}$ & $\begin{array}{c}94 \\
5\end{array}$ \\
\hline $\begin{array}{l}\text { Emaben, } \\
\text { cd.g.w. }\end{array}$ & $\begin{array}{c}\text { Emamectin } \\
\text { bensoat }\end{array}$ & 0,2 & 100 & $\begin{array}{c}87, \\
2\end{array}$ & $\begin{array}{c}87, \\
7\end{array}$ & 100 & $\begin{array}{c}93 \\
0\end{array}$ & 92,1 & $\begin{array}{c}96, \\
5\end{array}$ & 94 & $\begin{array}{c}92 \\
9\end{array}$ \\
\hline Decis, & Deltametrin & 0,5 & 100 & $\begin{array}{c}89, \\
9\end{array}$ & $\begin{array}{c}90 \\
3\end{array}$ & 100 & $\begin{array}{c}95 \\
2\end{array}$ & $\begin{array}{c}90 \\
3\end{array}$ & $\begin{array}{c}95 \\
5\end{array}$ & $\begin{array}{c}94 \\
1\end{array}$ & 93 \\
\hline
\end{tabular}


The American Journal of Agriculture and Boimedical Engineering

(ISSN - 2689-1018)

IMPACT FACTOR

Published: July 30, 2021| Pages: 11-20

Doi: https://doi.org/10.37547/tajabe/Volume03Issue07-02

2021: $5 \cdot 554$

OCLC - 1121105746

\begin{tabular}{|c|c|c|c|c|c|c|c|c|c|c|c|}
\hline 2,5 \% c.e.. & & & & & & & & & & & \\
\hline $\begin{array}{c}\text { Cypremetrin, } \\
25 \% \text { c.e.. }\end{array}$ & Cypremetrin & 0,3 & 100 & $\begin{array}{c}96 \\
6\end{array}$ & $\begin{array}{c}93 \\
5\end{array}$ & 100 & $\begin{array}{c}98, \\
0\end{array}$ & $\begin{array}{c}90 \\
1\end{array}$ & $\begin{array}{c}96 \\
5\end{array}$ & 94 & $\begin{array}{c}94 \\
3\end{array}$ \\
\hline $\begin{array}{l}\text { Imidogold, } \\
35 \% \text { к.с. }\end{array}$ & Imidocloprid & 0,2 & 100 & $\begin{array}{c}88, \\
9\end{array}$ & $\begin{array}{c}89, \\
4\end{array}$ & 100 & $\begin{array}{c}99, \\
0\end{array}$ & $\begin{array}{c}90 \\
4\end{array}$ & $\begin{array}{c}97 \\
8\end{array}$ & $\begin{array}{c}95 \\
6\end{array}$ & $\begin{array}{c}94 \\
5\end{array}$ \\
\hline $\begin{array}{l}\text { Pulsar, } \\
5 \% \text { c.e.. }\end{array}$ & $\begin{array}{c}\text { Lambdacigalotri } \\
\text { n }\end{array}$ & 0,4 & 100 & $\begin{array}{c}89, \\
9\end{array}$ & $\begin{array}{c}90 \\
3\end{array}$ & 100 & $\begin{array}{c}95, \\
4\end{array}$ & $\begin{array}{c}90 \\
3\end{array}$ & $\begin{array}{c}95 \\
5\end{array}$ & $\begin{array}{c}94, \\
1\end{array}$ & 93 \\
\hline $\begin{array}{l}\text { Control } \\
\text { (without } \\
\text { rocessing) }\end{array}$ & - & - & - & - & - & - & - & - & - & - & - \\
\hline
\end{tabular}

\section{CONCLUSION}

Despite the wide list of harmful organisms occupying a potato, it is developed nowadays and constantly updating the system of control against them to provide their phyto-sanitary condition's monitoring, and conducting a complex of warning and destroying measures of control against them to ensure data of losses till the economic-imperceptible sizes.

\section{REFERENCES}

1. Vilkova N.A., Sukhoruchenko G. I, Fasulati S.R. Strategy of agricultural plants protection from adventive kinds of insects-phytophages on an example of the Colorado potato beetle / The bulletin of plants protection, 2005, №3, -p.3-15.

2. Vlasova V. A, Petropavlovskaya T.P. The dangerous pest / Plants protection, 1986, №6, -p.38-39.

3. Zhimerikin V. N, Dudov M.V. Potato moth in the field and a storehouse / Plants protection and quarantine, 2009, №4, p.32-34.

4. Mamatov K.S., Obidzhanov D.A., Khodzhaev SH.T. The rust mite on Solanaceae / The Uzbek biological magazine, 2013, №4, - p.36-38.

5. Sukhoruchenko G. I, Dolzhenko V. I, Vasilyeva T.I., Ivanov S.G., Zverev A.A. The problem of Colorado potato beetles' resistance to modern insecticides / The modern systems of protection and new trends in increase of potato stability to the Colorado potato beetles (The series of genetic engineering and ecology). Moscow, "Science", 2000, №1, - p.93-100.

6. Ushatinskaya R.S. The Colorado potato beetle / Moscow, "Science", 1981, - p.377.

7. Fasulati S.R. Polymorphism and population structure of the Colorado potato beetle Leptinotarsa decemlineata Say (Coleoptera, Chrysomelidae) in the European part of the USSR. / Ecology, 1985, №6, - p.50-56.

8. Khodzhaev S.T. Entomology, protection of agricultural crops and basis of agro- 
The American Journal of Agriculture and Boimedical Engineering

IMPACT FACTOR (ISSN - 2689-1018)

Published: July 30, 2021| Pages: 11-20

Doi: https://doi.org/10.37547/tajabe/Volume03Issue07-02

OCLC - 1121105746

toxicology./Tashkent: "Navruz", 2013, p.540 (Uzb.)

9. Hare J.D. Ecology and management of the Colorado potato beetle./Ann. Rev. Entomol. - Palo Alto, 1990, №35, - p.81100.

10. Shelton A.M. Development and development of transgenic insecticidal crops in pest management.//Plant Protection towards $21^{\text {st }}$ Century. Proceed.

Of $\mathrm{XY}$ International Plant Protection Congress. - Beijing, China, 2004, - p.13-15. 